\title{
Efektivitas Kinerja Inkubator Bisnis Selama Pandemi Covid-19 Dari Perspektif Tenan: Studi Kasus Di KKIB Universitas Diponegoro
}

\author{
Omia Crefioza*, Amie Kusumawardhani \\ Magister Manajemen Universitas Diponegoro, Semarang \\ *Correspondence email: crefioza@gmail.com
}

\begin{abstract}
Abstrak. Penelitian ini bertujuan untuk menganalisis efektivitas kinerja inkubator bisnis KKIB Undip selama pandemi Covid-19 dari sudut pandang tenant. Metode yang digunakan dalam penelitian ini adalah metode kualitatif. Penelitian ini menggunakan data primer berupa hasil wawancara dengan dua orang tenant sebagai informan. Hasil penelitian ini menunjukkan bahwa terjadi penurunan dari segi kuantitas terhadap beberapa program selama pandemi Covid-19 berlangsung, seperti kegiatan mentoring, coaching, business matching dan pitching. Namun, dari segi kualitas, pelatihan yang diberikan oleh inkubator bisnis KKIB Undip sudah baik dilihat dari layanan dan program inkubator yang melebihi ekspektasi tenan. Disamping itu keefektivitasan inkubator juga ditinjau dari pertumbuhan bisnis tenant yang semakin membaik sejak bergabung dengan inkubator bisnis meskipun sedang dalam polemik pandemi Covid-19 seperti saat ini. Diharapkan pada penelitian berikutnya dapat mengkaji lebih dalam mengenai efektivitas kinerja inkubator bisnis universitas selama pandemi Covid-19 dari aspek yang berbeda.
\end{abstract}

Kata kunci: Covid-19; Efektivitas; Inkubator bisnis; Tenan

\begin{abstract}
This study aims to analyze the effectiveness of the performance of the Undip KKIB business incubator while Covid-19 pandemic from the tenant's point of view. The method used in this research is the qualitative method. This study uses primary data in the form of interviews within two tenants as informant The results of this study indicate that there has been a decrease in quantity in several programs during the Covid-19 pandemic, such as mentoring, coaching, business matching, and pitching activities. However, in terms of quality, the training provided by the Undip KKIB business incubator has been good in terms of services and incubator programs that exceed tenants' expectations. The effectiveness of the incubator is also viewed in terms of the tenant's business growth has been getting better since joining the business incubator even though it is currently in a polemic of the Covid-19 pandemic. For future researchers, examine more deeply the effectiveness of the performance of university business incubators during the Covid-19 pandemic from different aspects is expected.
\end{abstract}

Keywords: Business incubator; Covid-19; Effectiveness; Tenant

\section{PENDAHULUAN}

Pemerintah telah menyiapkan beberapa program untuk mengoptimalkan pembangunan ekonomi, salah satunya adalah dengan membentuk inkubator bisnis. Program inkubasi bisnis telah digunakan sebagai instrumen kebijakan pengembangan kewirausahaan untuk meningkatkan kelompok perusahaan baru dan menangani kebutuhan mereka pada tahap awal yang keberadaannya masih rentan (Dee et al.., 2011).

Inkubasi bisnis merupakan proses sosial dan manajerial yang bertujuan untuk mendukung pengembangan dan komersialisasi produk baru, teknologi baru, dan model bisnis baru (Eshun, 2009). Secara luas, inkubasi bisnis dapat diklasifikasikan menjadi dua domain: berbasis akademik dan berbasis industri.

Inkubator bisnis merupakan sebuah alat pengembangan ekonomi yang dirancang untuk membantu menciptakan bisnis baru di komunitas. Inkubator bisnis membantu bisnis baru dengan menyediakan berbagai layanan dukungan, seperti bantuan dalam mengembangkan rencana bisnis dan pemasaran, membangun tim manajemen, mendapatkan modal, dan akses ke berbagai layanan profesional yang lebih khusus. Mereka juga menyediakan ruang yang fleksibel, peralatan bersama, dan layanan administrasi (Sherman, 1999).

Barbero et al. (2012) dan Grimaldi \& Grandi (2005), mengartikan inkubator bisnis universitas sebagai institusi berbasis universitas yang memberikan dukungan bagi para pemula bisnis baru melalui layanan yang berwujud dan tidak berwujud. Sekitar sepertiga dari inkubator bisnis, sebagaimana dikemukakan oleh (Robles, 2017), bertempat di universitas dan kampus. Inkubator bisnis tersebut merupakan cara efisien untuk mencari kerja sama dan menciptakan jaringan yang menghasilkan nilai tambah. (Fernández Fernández et al., 2015) menjelaskan bahwa kemitraan inkubator bisnis universitas bermanfaat bagi pengusaha, mahasiswa, universitas dan inkubator itu sendiri.

Alasan utama dibentuknya inkubator bisnis di perguruan tinggi di Indonesia adalah untuk mengurangi permasalahan tingkat pengangguran, khususnya dari pengangguran terdidik. Menurut Ditjen Dikti, tingkat pengangguran terdidik yang masih terbilang tinggi itu bisa disebabkan oleh ketidaksiapan perguruan tinggi dalam menciptakan sistem pembelajaran yang mampu melahirkan sarjana produktif (sarjana yang dapat menciptakan lapangan pekerjaan) dan ditambah dengan minimnya kegiatan wirausaha/bisnis di dalam ruang 
lingkup perguruan tinggi. Di Indonesia baru ada 86 inkubator bisnis yang terdaftar di Kemenristekdikti, dengan 70 diantaranya berada di perguruan tinggi. Beberapa contoh berikut merupakan inkubator yang berada di perguruan tinggi seperti Incubie (IPB), Inkubator Industri dan Bisnis (ITB), Oorange (Unpad), KKIB (Undip), dan UPT Inkubator Industri (ITS).

Layanan dari inkubasi bisnis menurut (Hackett \& Dilts, 2004) termasuk ruang inkubasi bersama, nasihat dan pelatihan manajemen, akses bersubsidi ke sumber daya bisnis (teknis, keuangan, akuntansi, periklanan dan hukum) dan pinjaman kredibilitas bisnis, diperoleh melalui kemitraan dengan perusahaan yang sudah mapan dan biasanya disesuaikan dengan kebutuhan para inkubasi, serta fungsi jaringan.

Inkubator dituntut untuk memberikan lebih dari sekedar layanan dasar seperti sewa kantor dan coworking space bagi penyewa dengan berorientasi pada strategi. Hal ini diperlukan karena kemungkinan para tenan tidak memiliki banyak waktu untuk mencapai tujuannya seperti meningkatkan skala bisnisnya serta kurangnya sumber daya yang melimpah, baik manusia maupun finansial (Bosch et al., 2013). Beberapa jalur strategis sangat dibutuhkan seperti model bisnis untuk menghasilkan aliran pendapatan dari target market yang jelas. Hal ini menunjukkan perlunya memastikan perencanaan dan implementasi yang efisien oleh start up selaku tenan melalui eksperimen bisnis dan pembelajaran organisasi (Spender et al., 2017). Oleh karena itu, hal ini memberikan persepsi bagi penyewa tentang efektivitas inkubator bisnis pada bisnis mereka. Ini juga menunjukkan bahwa aspirasi mereka sangat penting untuk mengukur kinerja inkubator.

Disamping itu, dirasa perlu untuk meninjau seberapa efektif inkubator bisnis berjalan selama pandemi Covid-19 ini. Karena, seperti yang diketahui bersama bahwa inkubator bisnis mempunyai peran vital dalam pengembangan bisnis tenan selama ini. Apakah pandemi Covid-19 ini menurunkan efektivitas kinerja inkubator bisnis dan menghambat laju pertumbuhan bisnis tenan atau tidak? Untuk menjawab pertanyaan penelitian tersebut, maka dilakukanlah penelitian ini.

\section{METODE}

Metode yang digunakan dalam penelitian ini adalah metode kualitatif dengan jenis penelitian studi kasus. Penelitian ini bersifat eksplorasi. Dalam penelitian ini dilakukan wawancara terhadap dua orang informan dengan latar belakang yang berbeda. Untuk informan pertama masih berstatus diinkubasi di inkubator bisnis KKIB Undip, sedangkan informan kedua telah berstatus lulus / graduated dari proses inkubasi di inkubator bisnis KKIB Undip. Untuk data kedua informan tersebut tercantum pada tabel di bawah ini:

Tabel 1. Karakteristik Informan : Tenan

\begin{tabular}{|c|c|c|c|c|c|}
\hline No & Keterangan & Nama Usaha/ Jabatan & Bidang Usaha & Status Inkubasi & Kode \\
\hline 1 & Tenan & Indonesiatourguide & Pariwisata & Diinkubasi & R1 \\
\hline 2 & Tenan & Indofishery & Perikanan & Lulus & $\mathrm{R} 2$ \\
\hline
\end{tabular}

\section{HASIL DAN PEMBAHASAN}

\section{Efektivitas Inkubator Dari Segi Layanan Inkubator}

Dari wawancara yang dilakukan terhadap kedua tenan, didapatkan hasil bahwa layanan dan program yang telah diberikan oleh inkubator selama ini sudah sangat baik, hanya saja beberapa program berjalan dengan kurang maksimal pada saat pandemi Covid ini. Meskipun dilakukan secara virtual, intensitas kegiatan mentoring dan coaching mengalami penurunan pada tahun 2020 lalu. Hal ini sejalan dengan temuan dari beberapa penelitian sebelumnya (Baraldi \& Havenvid, 2016; Games et al., 2020) bahwa inkubator diharapkan oleh mayoritas narasumber untuk melakukan coaching secara berkala, dimana hal tersebut begitu diapresiasi oleh tenan.

Tabel 2. Pengelompokan Sub Tema: Layanan Inkubator

\begin{tabular}{ll}
\hline No & Kutipan Representatif \\
\hline 1 & "Jadi memang untuk beberapa kegiatan selama covid ini seperti coaching yang sifatnya \\
& massal itu memang jarang sekali dilaksanakan nggak seperti dulu sebelum Covid. Nah \\
& nampaknya memang setelah Covid ini untuk sistem mentoring ke tenan outwall dan inwall \\
& itu tetap dilaksanakan, walaupun dalam bentuk virtual, kayak gitu." (R2) \\
2 & "Kalau secara virtual ada tapi nggak se intens yang sebelum Covid. Sebelum covid itu \\
& sering, sering ada pelatihan di Inbis, kita diundang. Trus ada yang sering yang datang ke \\
& kantor-kantor kita dari Inbis. Kalo outwall ya datang ke kantor, kalau inwall biasanya \\
& lebih datang ke basement atau ke lantai satu itu nah buat kontrol. Buat yang outwall ini \\
& memang nggak begitu intens, jadi paling cuma dua tiga kali. Kalau biasanya dalam satu \\
& tahun malah bisa berkali-kali ya mbak kalo sebelum covid. Ya memang dari segi \\
& intensitasnya memang agak kurang." (R2)
\end{tabular}
Pengelompokan SubTema

Value-added service massal itu memang jarang sekali dilaksanakan nggak seperti dulu sebelum Covid. Nah nampaknya memang setelah Covid ini untuk sistem mentoring ke tenan outwall dan inwall sering sering ada pelatihan di Inbis, kita diundang. Trus ada yang sering yang datang ke Value-added service lebih datang ke basement atau ke lantai satu itu nah buat kontrol. Buat yang outwall ini tahun malah bisa berkali-kali ya mbak kalo sebelum covid Ya memang dari segi intensitasnya memang agak kurang." (R2) 
3 "Selama ini pendampingan gak tentu jadwalnya. Kadang 3 minggu sekali, 2 minggu sekali atau kadang bisa 1 bulan sekali. Dan juga untuk mengevaluasi tenan harus sebaiknya dilakukan setiap 2 minggu sekali sih. Jadi lebih ke jadwal gimana semuanya itu harus dilaporkan dalam jangka waktu tertentu. Jadi, dengan banyak komunikasi yang intens membuat tenan sama KKIB akan lebih cepat bertumbuh." (R1)

Namun, kondisi ini hanya terjadi saat pandemi Covid-19 berlangsung. Sebelum pandemi melanda negeri, program dan layanan yang diberikan oleh inkubator bisnis KKIB Undip berjalan normal, bahkan melebihi ekspektasi tenan.

\section{Efektivitas Inkubator Dari Segi Pertumbuhan Bisnis Tenan}

Dalam mengukur keefektivan suatu inkubator bisnis, tentu kita perlu meninjau kembali ke tujuan awal inkubator dibentuk. Seperti hasil penelitian Mian (1997) yang mengatakan bahwa dalam mengukur dan menilai
Value-added service

keefektivan inkubator bisnis dapat ditinjau dari pertumbuhan usaha tenan. Wawancara yang dilakukan terhadap kedua tenan sama-sama memberikan penilaian yang positif terhadap pertumbuhan bisnis mereka. Mereka sepakat, bahwa pertumbuhan bisnis tersebut tidak terlepas dari bantuan inkubator bisnis yang memegang andil cukup besar. Apalagi di tengah pandemi Covid-19 yang terjadi, kedua tenan mengatakan mampu untuk bertahan dan bahkan ada yang mampu melampaui target pada saat pandemi berlangsung.

Tabel 3. Pengelompokan Sub Tema: Pertumbuhan Bisnis Tenan

\begin{tabular}{|c|c|c|}
\hline No & Kutipan Representatif & Pengelompokan SubTema \\
\hline 1 & $\begin{array}{l}\text { "Ya, kalau kalau memang dari segi perkembangan bisnis, memang kalau dari apa } \\
\text { namanya, kalau dari profit atau keuntungan itu cukup bagus mbak, cukup meningkat ya.." } \\
(\mathbf{R} 2)\end{array}$ & Profitability \\
\hline 2 & $\begin{array}{l}\text { "Kalau profit, karena kita itu bisnis di pariwisata, saat itu kita sedang diinkubasi untuk } \\
\text { pembangunan sistem untuk digitalisasi pariwisata, yang kita dapatkan disitu adalah } \\
\text { penambahan investasi untuk modal. Untuk profit sendiri, kenaikan kita mungkin sekitar } \\
20 \% \text {, untuk awal. Dan harusnya di tahun } 2020 \text { itu profit kita target di sampe 50\%, tapi } \\
\text { kita harus WFH dan harus menghentikan sementara dahulu projek yang kita kerjakan } \\
\text { dikarenakan pandemi. Seperti itu." (R1) }\end{array}$ & Profitability \\
\hline 3 & $\begin{array}{l}\text { "Kalo awal-awal } 2020 \text { itu, mulai dari Februari akhir hingga Maret awal itu kita mulai } \\
\text { berdampak banget sih mbak. Kalau awal-awal covid kan ya gitu kan, tapi dampak kita } \\
\text { dampak positif. Jadi kita memang ada kenaikan. Kenaikan user, kenaikan penjualan yang } \\
\text { cukup signifikan. Dan alhamdulillah kita kontrol sampai saat ini, masih bertahan lah } \\
\text { untuk di, ya di pandemi covid ini memang menjadi salah satu titik balik kita. }(\boldsymbol{R} 2)\end{array}$ & Sustainability \\
\hline 4 & $\begin{array}{l}\text { "KKIB sangat membantu untuk memberikan semangat dalam melanjutkan bisnis, } \\
\text { membangun motivasi bagaimana kita harus tetap bertahan dan berjuang di kala pandemi, } \\
\text { itu sangat mereka lakukan. Dan, kepedulian KKIB tentang para tenannya itu sangat luar } \\
\text { biasa kalau saya bilang. Jadi, kita yang bisnisnya agak tersendat, kita yang bisnisnya } \\
\text { hampir sama sekali gak ada income, itu tetap dibantu bagaimana caranya kita tetep bisa } \\
\text { tidak bangkrut atau kita tidak menutup perusahaan. Mereka juga membantu bagaimana } \\
\text { caranya kita tetap menghasilkan suatu income melalui ide-ide yang kita bahas bersama } \\
\text { selama inkubasi secara virtual seperti itu." }(\boldsymbol{R} \mathbf{1})\end{array}$ & Sustainability \\
\hline
\end{tabular}

Berdasarkan hasil wawancara yang dirangkum, diperoleh hasil bahwa pertumbuhan bisnis tenan semakin meningkat pesat semenjak bergabung dengan inkubator bisnis KKIB Undip. Hal tersebut dapat diihat dari kenaikan profit, pengembangan sumberdaya berupa peningkatan SDM yang dimiliki tenan, dan kelangsungan hidup startup meskipun terjadi pandemi Covid-19.

\section{SIMPULAN}

Kinerja inkubator bisnis KKIB Undip selama ini sudah cukup efektiv menurut sudut pandang tenan. Hal tersebut diukur dari 2 aspek, yaitu program yang diberikan oleh inkubator bisnis dan dari segi pertumbuhan bisnis tenan. Hanya saja, memang dari segi program yang diberikan oleh inkubator bisnis terhadap tenan selama pandemi Covid-19 mengalami penurunan kuantitas. Sedangkan ditinjau dari segi pertumbuhan dan kelangsungan hidup usaha tenan terjadi peningkatan yang sesuai dengan harapan para tenan bahkan ada yang melebihi ekspektasi.

Tenan pertama, meskipun pendapatan usahanya tidak mencapai tartget awal, namun ia mampu untuk bertahan di situasi pandemi seperti ini dan tidak menutup usahanya. KKIB banyak membantu dari segi memberikan motivasi dan memberikan ide-ide kreatif untuk kelangsungan hidup usahanya tersebut. Sedangkan tenan kedua mampu menjadikan pandemi ini sebagai titik balik baginya untuk melangkah sangat jauh melebihi target yang telah dibangunnya. Hal ini tentu 
tidak terluput dari bantuan dan bimbingan yang diberikan oleh inkubator bisnis KKIB selama ini terhadap tenan-tenannya.

Diharapkan pada penelitian berikutnya dapat mengkaji lebih dalam mengenai efektivitas kinerja inkubator bisnis universitas selama pandemi Covid-19 dari aspek yang berbeda.

\section{DAFTAR PUSTAKA}

Baraldi, E., \& Ingemansson Havenvid, M. (2016). Identifying new dimensions of business incubation: A multi-level analysis of Karolinska Institute's incubation system. Technovation. https://doi.org/10.1016/j.technovation.2015.08.00 3

Barbero, J. L., Casillas, J. C., Ramos, A., \& Guitar, S. (2012). Revisiting incubation performance. How incubator typology affects results. Technological Forecasting and Social Change, 79(5), 888-902. https://doi.org/10.1016/j.techfore.2011.12.003

Bosch, J., Olsson, H. H., Björk, J., \& Ljungblad, J. (2013). The early stage software startup development model: A framework for operationalizing lean principles in software startups. Lecture Notes in Business Information Processing. https://doi.org/10.1007/978-3-64244930-7_1

Dee, N., Gill, D. E., Livesey, T. F., \& Minshall, T. H. W. (2011). Incubation for growth: A review of the impact of business incubation on new ventures with high growth potentiaNn. September.

Eshun, J. P. (2009). Business incubation as strategy. Business Strategy Series. https://doi.org/10.1108/17515630910956570

Fernández Fernández, M. T., Blanco Jiménez, F. J., \& Cuadrado Roura, J. R. (2015). Business incubation: innovative services in an entrepreneurship ecosystem. Service Industries Journal, 35(14), 783-800. https://doi.org/10.1080/02642069.2015.1080243

Games, D., Kartika, R., Sari, D. K., \& Assariy, A. (2020). Business incubator effectiveness and commercialization strategy: a thematic analysis. Journal of Science and Technology Policy Management. https://doi.org/10.1108/JSTPM-032020-0067

Grimaldi, R., \& Grandi, A. (2005). Business incubators and new venture creation: An assessment of incubating models. Technovation. https://doi.org/10.1016/S0166-4972(03)00076-2

Hackett, S. M., \& Dilts, D. M. (2004). A Systematic Review of Business Incubation Research. The Journal of Technology Transfer. https://doi.org/10.1023/b:jott.0000011181.11952.0 $\mathrm{f}$

Mian, S. A. (1997). Assessing and managing the university technology business incubator: An integrative framework. Journal of Business Venturing. $\quad$ https://doi.org/10.1016/S08839026(96)00063-8

Robles, N. M. H. (2017). Development of University's Business Incubators in Panama. Faculty of Engineering Economics and Management, Institute of Business, Riga Technical University.

Sherman, H. D. (1999). Assessing the intervention effectiveness of business incubation programs on new business start-ups. In Journal of Developmental Entrepreneurship.

Spender, J. C., Corvello, V., Grimaldi, M., \& Rippa, P. (2017). Startups and open innovation: a review of the literature. In European Journal of Innovation Management. https://doi.org/10.1108/EJIM-122015-0131 